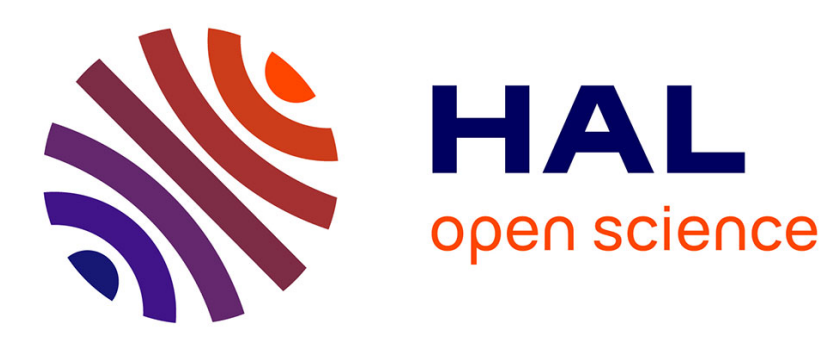

\title{
CONICAL EMISSION AT LIGHT SELF-FOCUSING IN RESONANT MEDIA
}

\author{
A. Afanas'Ev, B. Samson
}

\section{To cite this version:}

A. Afanas'Ev, B. Samson. CONICAL EMISSION AT LIGHT SELF-FOCUSING IN RES-

ONANT MEDIA. Journal de Physique IV Proceedings, 1991, 01 (C7), pp.C7-787-C7-787. 10.1051/jp4:19917214 . jpa-00250923

\section{HAL Id: jpa-00250923 https://hal.science/jpa-00250923}

Submitted on 1 Jan 1991

HAL is a multi-disciplinary open access archive for the deposit and dissemination of scientific research documents, whether they are published or not. The documents may come from teaching and research institutions in France or abroad, or from public or private research centers.
L'archive ouverte pluridisciplinaire HAL, est destinée au dépôt et à la diffusion de documents scientifiques de niveau recherche, publiés ou non, émanant des établissements d'enseignement et de recherche français ou étrangers, des laboratoires publics ou privés. 


\title{
CONICAL EMISSION AT LIGHT SELF-FOCUSING IN RESONANT MEDIA
}

\author{
A.A. AFANAS'EV and B.A. SAMSON
}

Institute of Physics, BSSR Acad. Sci, Minsk 220602, USSR

In the present work we report the results of a theoretical study of conical emission (CE), observed in experiments on propagation of powerful laser beams in alkali vapors [1]. We proceeded from an assumption that $\mathrm{CE}$ is excited due to four-photon scattering processes. In a stationary, about the $\mathrm{z}$ axis, pump field of the filament type formed as a result of self-focusing of a powerful field in the resonant-absorbing medium, the interaction of waves $E_{ \pm}\left(r_{\perp}\right)$ is descrlbed by:

$i \frac{\partial E_{ \pm}}{\partial z}+\left(2 k_{ \pm}\right)^{-1} \Delta_{\perp} E_{ \pm}=i x_{ \pm}\left(r_{\perp}\right) E_{ \pm}+i \beta_{ \pm}\left(r_{\perp}\right) E_{+}^{*} \exp (2 i \gamma z)=0$,

where $x_{ \pm}$and $\beta_{ \pm}$are normalized susceptibilities and coefficients of wave coupling in resonant media, $\gamma$ is the nonlinear change of pump wave number. After replacing $E_{+}=\mathscr{E}_{+}\left(\mathrm{r}_{\perp}\right) \exp (i \Gamma z)$ and $E_{-}^{*}=\varepsilon_{-}\left(\mathrm{r}_{\perp}\right) \exp (i \Gamma z)$ equations (1) are reduced to the eigenvalue problem with eigenvalues $\Gamma_{n}$ allowing to determine the $E_{ \pm}\left(\omega_{ \pm}\right)$waves scattering angles.

Search for the eigenvalues led to the following results:

- It is shown that, under a weak modulation of the resonance medium characteristics by pumping, the conditions for the waveguide trapping of the weak field by the filament are fulfilled only for the blue wing component of the resonantly scattered emission. As a result, this forms the central spot, and the red wing component parametrically coupled with it is emitted into a cone at angles determined by the so called "Cherenkov" synchronism rule;

- The possibility of non-threshold amplification of the parametrically coupled waves in the spatially bounded pump field has been established;

- It is shown that, with considerable amplification of weak waves, the angles of their scattering from the filament do not follow the models based on their phase matching and can exceed the known values of exact phase matching angles. 1.D.J.Harter,R.W.Boyd. Phys.Rev.A,29,739 (1984). 